\title{
PENGARUH LINGKUNGAN KERJA TERHADAP KINERJA KARYAWAN PADA PT NATIONAL FINANCE
}

\author{
Herwin Tri Munardi', Tjipto Djuhartono ${ }^{2}$, Nur Sodik ${ }^{3}$, \\ Universitas Indraprasta Persatuan Guru Republik Indonesia \\ Email: herwintrimunardi@gmail.com ${ }^{1}$, tjiptodjuhartono@gmail.com², \\ nur.sodik@unindra.ac.id ${ }^{3}$
}

\begin{abstract}
Purpose. The purpose of this study was to determine the effect of the work environment on employee performance at PT National Finance.

Methods. The research was conducted using the Associative method. The population in this study were all employees of PT National Finance with a sample size of 40 respondents, the sampling technique used was saturated sampling. The instrument used in the form of a questionnaire with 18 statements. Data analysis used simple linear regression.
\end{abstract}

Findings. The results of hypothesis testing obtained that the work environment has a positive and significant effect on employee performance at PT National Finance, this can be proven from the tcount 10,830 > ttable 2,024. This shows that the better the state of the employee's work environment, the more employee performance will improve.

Implication. PT National Finance must pay attention to, evaluate and optimize aspects of the Work Environment, besides that it must also be able to add good values in the Work Environment, so that employees can improve their performance, to support the progress of the company.

Keywords. Work Environment, Employee Performance.

\begin{abstract}
ABSTRAK
Tujuan. Tujuan penelitian ini adalah untuk mengetahui pengaruh lingkungan kerja terhadap kinerja karyawan pada PT National Finance.

Metode. Penelitian dilakukan dengan metode Asosiatif. Populasi dalam penelitian ini adalah seluruh karyawan PT National Finance dengan besar sampel sebanyak 40 responden, dengan teknik sampling yang digunakan yaitu sampling jenuh. Instrumen yang digunakan berupa kuesioner sebanyak 18 pernyataan. Analisis data menggunakan regresi linier sederhana.

Hasil. Hasil pengujian hipotesis diperoleh Lingkungan kerja berpengaruh positif dan signifikan terhadap kinerja karyawan Pada PT National Finance, hal tersebut dapat dibuktikan dari nilai $t_{\text {hitung }} 10,830>t_{\text {tabel }} 2,024$. Hal tersebut menunjukan bahwa semakin baik keadaan lingkungan kerja karyawan maka akan semakin meningkatkan kinerja karyawan.

Implikasi. PT National Finance harus memperhatikan, mengevaluasi dan mengoptimalkan aspek-aspek Lingkungan Kerja, selain itu juga harus dapat menambahkan nilai-nilai yang baik dalam Lingkungan Kerja, sehingga karyawan dapat meningkatkan kinerja mereka, untuk mendukung kemajuan perusahaan.
\end{abstract}

Kata Kunci : Lingkungan Kerja, Kinerja Karyawan 


\section{Pendahuluan}

Industri pembiayaan hadir seiring dengan perkembangan otomotif di Indonesia sekitar tahun 1974. Surat keputusan bersama (SKB) tiga menteri, yaitu Menteri Keuangan, Menteri Perindustrian, dan Menteri Perdagangan, yang menjadi landasan kehadiran industri pembiayaan. Perusahaan pembiayaan mengalami pasang surut seiring dengan perekonomian nasional. Jenis barang yang dibiayai oleh perusahaan pembiayaan semakin luas dari waktu ke waktu. Perusahaan pembiayaan fokus pada pembiayaan transportasi seperti kendaraan roda 4 dan roda 2 pada tahap awal. Pembiayaan telah berkembang pada peralatan manufaktur, konstruksi, pertambangan, pertanian, perkantoran, peralatan medis dan perkapalan, (Johan, 2017:18).

PT National Finance merupakan perusahaan pembiayaan terbaik dan terkemuka di Indonesia khususnya wilayah kota Jakarta yang hadir untuk melayani beragam pembiayaan modal kerja. Hal ini berdampak pada tuntutan pengembangan kompetensi karyawan sesuai dengan persyaratan jabatan yang ada. Namun demikian, dalam upaya menciptakan kinerja karyawan PT National Finance, nampaknya masih terdapat banyak kendala yang dihadapi sehingga sulit untuk mencapai tujuan perusahaan. Kondisi yang belum ideal masih ada di PT National Finance. Kinerja pada karyawan PT National Finance masih belum optimal.

Hasil pengamatan penulis di PT National Finance menunjukkan bahwa masih terdapat indikasi masih kurang baiknya kinerja dari karyawan seperti kurangnya inisiatif dan kreatifitas dari karyawan dalam melaksanakan tugas-tugas dalam pekerjaan diduga menjadi salah satu faktor yang mendeskripsikan bahwa keingan berprestasi karyawan masih rendah. Karyawan sering melakukan kesalahan dalam bekerja sehingga hasil kerja tidak sesuai dengan yang di inginkan, Karyawan belum mampu meningkatkan jumlah (kuantitas) pekerjaan yang sudah ditetapkan. Karyawan belum dapat menyelesaikan pekerjaan secara tepat waktu dan memberikan laporan tugas yang diberikan pimpinan dengan cepat dan tepat waktu. Selain itu kurangnya kemandirian karyawan dalam melakukan pekerjaan dan selalu menunggu perintah dari atasan tanpa adanya inisiatif dalam bekerja.

Kinerja karyawan yang rendah harus mendapat perhatian lebih lanjut dari PT National Finance, mengingat kinerja karyawan akan mencerminkan tingkat kinerja yang akan dicapai oleh perusahaan secara keseluruhan. Banyak faktor yang mempengaruhi kinerja karyawan menurun, menurut Kasmir (2016:88) kinerja karyawan dipengaruhi oleh beberapa variabel yaitu: Kemampuan dan keahlian, pengetahuan, rancangan kerja, kepribadian, motivasi kerja, loyalitas kerja, kepemimpinan, gaya kepemimpinan, budaya organisasi, kepuasan kerja, lingkungan kerja sekitar, komitmen dan disiplin kerja.

Faktor yang sangat berpengaruh terhadap kinerja karyawan adalah faktor lingkungan kerja. Sedarmayanti (2017:135) mengemukakan bahwa lingkungan kerja adalah suatu tempat yang terdapat sebuah kelompok dimana di dalamnya terdapat beberapa fasilitas pendukung untuk mencapai tujuan perusahaan sesuai dengan visi dan misi perusahaan. Lingkungan yang dibina dalam perusahaan PT National Finance diperlukan untuk mencapai tujuan perusahaan, karena dengan lingkungan kerja yang nyaman, aman dan fasilitas karyawan yang terpenuhi akan mendorong karyawan untuk melakukan pekerjaan dengan optimal. Untuk mewujudkan lingkungan kerja yang kondusif perlu melibatkan pemimpin, manajemen dan karyawan itu sendiri.

Lingkungan kerja di PT National Finance berdasarkan pengamatan penulis masih terlihat kurang kondusif dapat dilihat dari: (1) ruang gerak dalam bekerja kurang luas sehingga para karyawaan kurang leluasa dalam bekerja, (2) kurangnya pentilasi udara yang terdapat diruangan kerja sehingga sirkulasi/pertukaran udara kurang lancar membuat 
ruangan menjadi panas dan membuat karyawan tidak nyaman, (3) konflik dalam perusahaan juga sering terjadi karena masalah diluar perusahaan seperti tersinggung karena ejekan dan senioritas, (4) dibeberapa ruangan masih ada yang pengap sehingga menimbulkan bau, (5) dari unit sarana yang sering mengeluh mengenai tidak adanya pengecekan secara berkala terhadap pendingin ruangan di tempat kerja sehingga menganggu aktivitas kerja karyawan.

Lingkungan kerja yang baik dapat menciptakan suasana kekeluargaan diantara sesama rekan kerja, dan juga suasana ruang kerja yang kondusif. Hal tersebut dapat memberikan reaksi positif bagi pegawai untuk membangkitkan semangat dan kegairahan kerja. Penelitian Adi dan Soehari (2016) menguji pengaruh lingkungan kerja terhadap kinerja karyawan, dimana penelitian ini menghasilkan pendapat bahwa kinerja karyawan akan meningkat dikarenakan oleh lingkungan kerja yang baik. Penelitian lain yang dilakukan oleh Palampanga (2017) menemukan bahwa lingkungan kerja dapat memberikan pengaruh yang positif dan signfikan terhadap kinerja karyawan. Dimana apabila lingkungan kerja mengalami kenaikan maka kinerja karyawan juga akan meningkat.

\section{Kajian Pustaka dan Hipotesis}

Lingkungan Kerja. Menurut Afandi (2018:65) lingkungan kerja adalah segala sesuatu yang ada disekitar karyawan dan dapat mempengaruhi dalam menjalankan tugas yang diembankan kepadanya misalnya dengan adanya air conditioner (AC), penerangan yang memadai sebagainya. Menurut Sedarmayanti (2017:9) lingkungan kerja adalah keseluruhan alat perkakas dan bahan yang dihadapi, lingkungan sekitarnya dimana seseorang bekerja, metode kerjanya, serta pengaturan kerjanya baik sebagai perseorangan maupun sebagai kelompok.

Menurut Sutrisno (2017:132) lingkungan kerja adalah keseluruhan sarana dan prasarana kerja yang ada di sekitar karyawan yang sedang melakukan pekerjaan yang dapat mempengaruhi pelaksanaan pekerjaan. Sedangkan menurut Kasmir (2016:77) Lingkungan kerja merupakan sarana dan prasarana atau kondisi pada sekitar lokasi tempat bekerja. Lingkungan kerja dapat berupa ruangan, layout, sarana dan prasarana, serta hubungan kerja dengan sesama rekan kerja.

Dari beberapa pendapat para ahli di atas, maka dapat disimpulkan bahwa lingkungan kerja merupakan segala sesuatu yang ada di sekitar karyawan pada saat bekerja, baik yang berbentuk fisik maupun nonfisik, yang dapat mempengaruhi dirinya dalam menjalankan tugas-tugas dan pekerjaannya sehari-hari.

Menurut Sedarmayanti (2017:45) dimensi dan indikator lingkungan kerja adalah sebagai berikut:

1) Lingkungan Kerja Fisik

a) Pencahayaan

Pencahayaan adalah faktor penting dalam lingkungan kerja. Karena dengan pencahayaan yang baik akan membantu dalam menyelesaikan tugas dengan lebih efektif.

b) Sirkulasi ruang kerja

Oksigen merupakan gas yang dibutuhkan oleh mahluk hidup untuk menjaga kelangsungan hidup, yaitu untuk proses metabolisme. Udara di sekitar dikatakan kotor apabila kadar oksigen, dalam udara tersebut telah berkurang dan telah bercampur dengan gas atau bau-bauan yang berbahaya bagi kesehatan tubuh.

c) Tata letak ruang Penataan letak ruangan kerja yang baik akan lebih mendorong terciptanya kenyamanan karyawan dalam bekerja. 
d) Dekorasi

Dekorasi ada hubungannya dengan tata warna yang baik, karena itu dekorasi tidak hanya berkaitan dengan hasil ruang kerja saja tetapi berkaitan juga dengan cara mengatur tata letak, tata warna, perlengkapan, dan lainnya untuk bekerja.

e) Kebisingan

Pekerjaan membutuhkan konsentrasi, maka suara bising hendaknya dihindarkan agar pelaksanaan pekerjaan dapat dilakukan dengan efisien sehingga produktivitas kerja meningkat.

f) Fasilitas

Fasilitas perusahaan sangat dibutuhkan oleh karyawan sebagai pendukung dalam menyelasikan pekerjaan yang ada di perusahaan. Tersedianya fasilitas kerja yang lengkap, walaupun tidak baru merupakan salah satu penunjang proses kelancaran dalam bekerja.

2) Lingkungan Kerja Non Fisik

a) Hubungan dengan pimpinan

Hubungan atasan dengan bawahan atau karyawannya harus di jaga dengan baik dan harus saling menghargai antara atasan dengan bawahan, dengan saling menghargai maka akan menimbulkan rasa hormat diantara individu masing-masing.

b) Hubungan sesama rekan kerja

Hubungan dengan rekan kerja yaitu hubungan dengan rekan kerja yang harmonis dan tanpa saling intrik di antara sesama rekan sekerja. Salah satu faktor yang dapat mempengaruhi karyawan tetap tinggal dalam satu organisasi adalah adanya hubungan yang harmonis dan kekeluargaan

Kinerja Karyawan. Menurut Afandi (2018:83) Kinerja adalah hasil kerja yang dapat dicapai oleh seseorang atau kelompok orang dalam suatu perusahaan sesuai dengan wewenang dan tanggung jawab masing-masing dalam upaya pencapaian tujuan organisasi secara illegal, tidak melanggar hukum dan tidak bertentangan dengan moral dan etika. Menurut Wibowo (2015:4) Kinerja adalah implementasi dari rencana yang telah disusun tersebut. Implementasi kinerja dilakukan oleh sumber daya manusia yang memiliki kemampuan, kompetensi, motivasi, dan kepentingan. Bagaimana organisasi menghargai dan memperlakukan sumber daya manusianya akan memengaruhi sikap dan perilakunya dalam menjalankan kinerja.

Menurut Rivai (2016:309), kinerja merupakan perilaku nyata yang ditampilkan setiap orang sebagai prestasi kerja yang dihasilkan oleh pegawai sesuai dengan perannya dalam perusahaan. Menurut Mangkunegara (2016:67) kinerja adalah hasil kerja secara kualitas dan kuantitas yang dicapai oleh seseorang pegawai dalam melaksanakan tugasnya sesuai dengan tanggungjawab yang diberikan kepadanya. Sedangkan menurut Hasibuan (2016:138), kinerja karyawan suatu hasil yang dicapai oleh seseorang dalam melaksanakan tugas-tugas yang dibebankan kepadanya.

Dari beberapa pendapat diatas maka dapat disimpulkan bahwa kinerja merupakan hasil kerja yang dicapai oleh seseorang pegawai sesuai dengan pekerjaan yang diberikan kepadanya dalam waktu tertentu. Kinerja juga merupakan perwujudan kerja yang dilakukan oleh pegawai yang biasanya digunakan sebagai dasar penilaian terhadap pegawai atau organisasi. Kinerja yang baik merupakan suatu langkah utama untuk menuju tercapainya suatu tujuan organisasi.

Dimensi dan Indikator kinerja karyawan menurut Mangkunegara (2016:67) adalah sebagai berikut :

1) Kualitas Kerja

Merupakan hasil kerja keras dari para pegawai yang sesuai dengan tujuan yang telah 
ditetapkan oleh pihak perusahaan sebelumnya. Jika hasil yang dicapai oleh pegawai tersebut tinggi maka kinerja dari pegawai tersebut dianggap baik oleh pihak perusahaan atau sesuai dengan standar yang telah ditetapkan. Ini berarti merupakan suatu tingkatan yang menunjukkan proses pekerjaan atau hasil yang dicapai atas suatu pekerjaan mendekati adanya kesempurnaan.

2) Kuantitas Kerja

Merupakan hasil kerja keras dari pegawai yang bisa mencapai skala maksimal yang telah ditentukan oleh pihak perusahaan. Kuantitas kerja menunjukkan jumlah pekerjaan yang dihasilkan individu atau kelompok sebagai persyaratan yang menjadi standar pekerjaan. Setiap pekerjaan memiliki persyaratan yang berbeda sehingga menuntut karyawan harus memenuhi persyaratan tersebut baik pengetahuan, keterampilan, maupun kemampuan yang sesuai.

3) Tanggung Jawab

Menunjukan seberapa besar pegawai dalam menerima dan melaksanakan pekerjaannya, mempertanggung jawabkan hasil kerja serta sarana dan prasarana yang digunakan dan perilaku kerjanya setiap hari.

4) Kerjasama

Dengan adanya pegawai yang mempunyai rasa harga diri yang tinggi terhadap pekerjaannya maka pegawai berusaha untuk mencapai hasil terbaik dalam pekerjaan tersebut. Oleh karena itu dengan rasa harga diri yang tinggi terhadap pekerjaannya diharapkan para pegawai dapat meningkatkan kinerja dalam bekerja. Kemampuan bekerja sama yang merupakan suatu tingkatan keadaan dari pegawai dapat menciptakan suasana nyaman dalam bekerja, percaya diri, komunikasi yang baik antar rekan kerja sehingga tercipta peningkatan kinerja.

5) Inisiatif

Inisiatif dari dalam diri anggota perusahaan untuk melakukan pekerjaan serta mengatasi masalah dalam pekerjaan tanpa menunggu perintah dari atasan atau menunjukan tanggung jawab dalam pekerjaan yang sudah menjadi kewajiban pegawai.

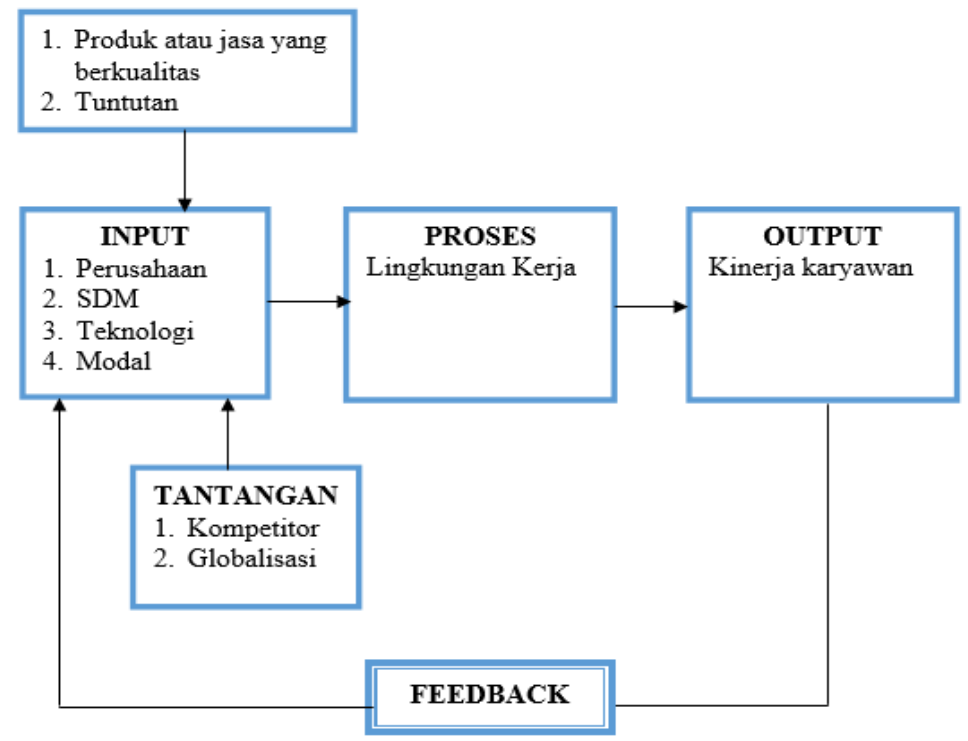

Gambar 1. Kerangka Berpikir 


\section{Hipotesis}

Menurut Sugiyono (2017:134), "hipotesis merupakan jawaban sementara terhadap rumusan masalah, dimana rumusan penelitian telah dinyatakan dalam bentuk kalimat pernyataan". Dikatakan sementara karena jawaban yang diberikan baru didasarkan pada teori yang relevan, belum didasarkan pada fakta-fakta empiris yang diperoleh melalui pengumpulan data. Adapun hipotesis dalam penelitian ini adalah sebagai berikut:

Terdapat pengaruh positif dan signifikan lingkungan kerja terhadap kinerja karyawan pada PT. National Finance.

\section{Metode Penelitian}

Jenis penelitian ini adalah penelitian kuantitatif. Penelitian kuantitatif digunakan dalam penelitian ini, karena data yang menjadi objek dalam penelitian ini merupakan data-data kuantitatif yang berupa angka-angka yang dihasilkan dari skala likert (Sugiyono, 2017:13). Metode yang digunakan dengan metode Asosiatif. Menurut Sugiyono (2017:44) "metode asosiatif adalah penelitian yang bertujuan untuk mengetahui pengaruh atau hubungan antara dua variabel lebih".

Populasi dalam penelitian ini adalah seluruh karyawan back office pada PT National Finance sebanyak 40 orang karyawan. Teknik pengambilan sampel dalam penelitian ini menggunakan metode teknik sampling jenuh. Menurut Sugiyono (2017:20) "sampling Jenuh adalah teknik penentuan sampel bila semua anggota populasi digunakan sebagai sampel". Maka jumlah sampel yang digunakan dalam peneliian ini adalah berjumlah 40 orang responden. Metode analisis yang dilakukan dalam penelitian ini adalah dengan analisis regresi linier sederhana, koefisien korelasi, koefisien determinasi, dan uji hipotesis.

\section{Hasil Penelitian dan Pembahasan Uji Validitas}

Validitas adalah suatu ukuran yang menunjukkan tingkat-tingkat kevalidan atau kesahihan suatu instrumen Arikunto (2016:168). Sebuah Uji Validitas dilakukan untuk mengukur sah atau tidaknya indikator atau kuesioner dari masing-masing variabel. Cara menguji validitas dengan membandingkan antara $r_{\text {hitung }}$ dengan $r_{\text {tabel }}$ dengan tingkat kesalahan (signifikan) 5\%. Sedangkan nilai $r_{\text {tabel }}$ dalam penelitian ini dengan signifikasi 0,05 dan jumlah Sampel $\mathrm{n}=45$ dengan rumus $\mathrm{DF}=\mathrm{n}-2$ yang berarti $40-2=38$ melihat tabel distribusi maka nilai $r_{\text {tabel }}$ adalah $=0,312$.

1) Bila nilai $r_{\text {hitung }}>r_{\text {tabel}}$, maka item pertanyaan valid.

2) Bila nilai $r_{\text {hitung }}<r_{\text {tabel}}$, maka item pertanyaan tidak valid

Tabel 1. Hasil Uji Validitas

\begin{tabular}{|c|c|c|c|}
\hline Pernyataan & Nilai $\mathbf{r}_{\text {hitung }}$ & Nilai rabel $_{\text { }}$ & Keterangan \\
\hline Lingkungan Kerja & & \\
\hline Pernyataan 1 & 0,583 & 0,312 & Valid \\
\hline Pernyataan 2 & 0,801 & 0,312 & Valid \\
\hline Pernyataan 3 & 0,778 & 0,312 & Valid \\
\hline Pernyataan 4 & 0,803 & 0,312 & Valid \\
\hline Pernyataan 5 & 0,836 & 0,312 & Valid \\
\hline Pernyataan 6 & 0,759 & 0,312 & Valid \\
\hline Pernyataan 7 & 0,744 & 0,312 & Valid \\
\hline Pernyataan 8 & 0,705 & 0,312 & Valid \\
\hline Kinerja Karyawan \\
\hline \multicolumn{4}{|l|}{} \\
\hline
\end{tabular}




\begin{tabular}{|c|c|c|c|}
\hline Pernyataan & Nilai $\mathbf{r}_{\text {hitung }}$ & Nilai $\mathbf{r}_{\text {tabel }}$ & Keterangan \\
\hline Pernyataan 2 & 0,778 & 0,312 & Valid \\
\hline Pernyataan 3 & 0,798 & 0,312 & Valid \\
\hline Pernyataan 4 & 0,859 & 0,312 & Valid \\
\hline Pernyataan 5 & 0,896 & 0,312 & Valid \\
\hline Pernyataan 6 & 0,865 & 0,312 & Valid \\
\hline Pernyataan 7 & 0,913 & 0,312 & Valid \\
\hline Pernyataan 8 & 0,867 & 0,312 & Valid \\
\hline Pernyataan 9 & 0,863 & 0,312 & Valid \\
\hline Pernyataan 10 & 0,784 & 0,312 & Valid \\
\hline
\end{tabular}

Sumber: Data diolah Excel (2021)

Berdasarkan hasil uji validitas tersebut maka dapat dijelaskan bahwa keseluruhan nilai $r_{\text {hitung }}$ lebih besar dari $r_{\text {tabel }}$ 0,312 dengan demikian maka dapat disimpulkan bahwa semua item dalam indikator variabel lingkungan kerja dan kinerja karyawan adalah valid. Sehingga tidak ada item pernyataan yang dihapus dan semua item pernyataan dapat digunakan pada keseluruhan model pengujian.

\section{Uji Reliabilitas}

Menurut Arikunto (2015:89), reliabilitas adalah suatu pengukuran yang menunjukkan stabilitas dan konsistensi dari suatu variabel yang mengukur suatu konsep untuk mengakses dari suatu pengukuran.

Tabel 2. Hasil Uji Reliabilitas

\begin{tabular}{|c|l|c|c|c|}
\hline No & Variabel & Cronbach Alpha & Nilai Kritis & Keputusan \\
\hline 1 & Lingkungan Kerja & 0,890 & 0,60 & Reliabel \\
\hline 2 & Kinerja Karyawan & 0,940 & 0,60 & Reliabel \\
\hline
\end{tabular}

Sumber: Data diolah Excel (2021)

Berdasarkan tabel diatas dapat diketahui bahwa variabel lingkungan kerja dan kinerja karyawan memiliki nilai cronbach alpha $>0,60$. Dengan demikian, maka hasil uji reliabilitas terhadap variabel lingkungan kerja dan kinerja karyawan adalah reliabel. Dengan kata lain bahwa seluruh pernyataan pada penelitian ini memiliki tingkat kehandalan yang baik dan dapat digunakan dalam analisis berikutnya.

\section{Regresi Linier Sederhana}

Analisis regresi linier sederhana digunakan untuk mengukur besarnya pengaruh variabel bebas terhadap variabel terikat dan memprediksi variabel terikat dengan menggunakan variabel bebas. Berikut hasil persamaan regresi linier sederhana.

\section{$Y=2,684+1,157 X$}

Dimana $\mathrm{X}=$ Lingkungan Kerja

$\mathrm{Y}=$ Kinerja Karyawan

Jika nilai $\mathrm{X}=0$ akan diperoleh $\mathrm{Y}=2,684$

Artinya nilai (a) atau konstanta sebesar 2,684 nilai ini menunjukan bahwa pada saat lingkungan kerja $(\mathrm{X})$ bernilai nol atau tidak meningkat, maka kinerja karyawan $(\mathrm{Y})$ akan tetap bernilai 2,684 koefisien regresi nilai (b) sebesar 1,157 (positif) yaitu menunjukkan pengaruh yang searah yang artinya jika lingkungan kerja ditingkatkan sebesar satu satuan maka akan meningkatkan kinerja karyawan sebesar 1,157 satuan.

\section{Koefisien Korelasi}

Korelasi menjelaskan tentang bagaimana tingkat keeratan hubungan suatu variabel independen dengan variabel dependen dalam suatu sistem korelasi ganda, setelah mengontrol 
atau mengendalikan variabel independen lainnya. Hasil perhitungan korelasi dengan cara manual sebagai berikut:

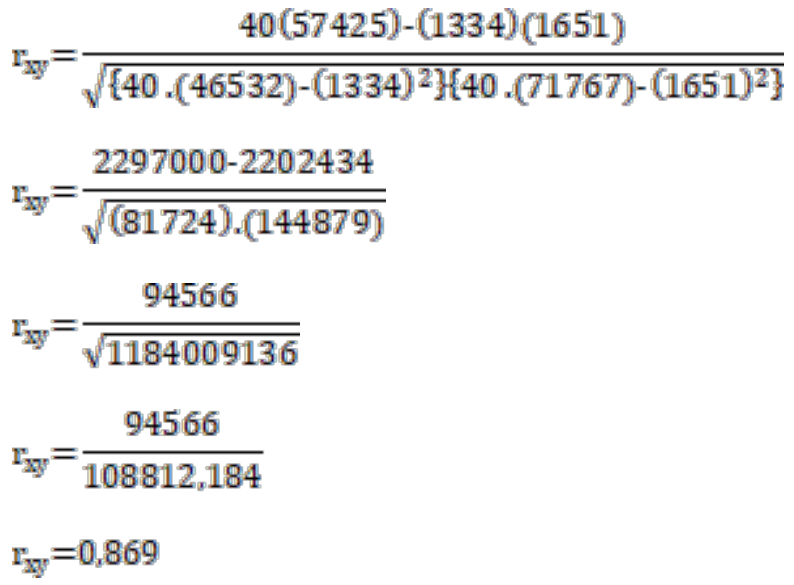

Berdasarkan hasil perhitungan tersebut dapat diketahui bahwa nilai korelasi sebesar 0,869 masuk dalam interval 0,80 - 1,00 dengan tingkat hubungan yang sangat kuat. Sehingga dapat dikatakan bahwa tingkat kekuatan hubungan lingkungan kerja terhadap kinerja karyawan memiliki tingkat hubungan yang sangat kuat.

\section{Koefisien Determinasi}

Analisis koefisien determinasi digunakan untuk mengetahui seberapa besar kontribusi variabel independen mempengaruhi variabel dependen dan hasilnya dalam bentuk prosentase. Hasil perhitungan koefisien determinasi dengan rumus sebagai berikut :

$$
\begin{aligned}
\mathbf{K D} & =(\mathbf{r})^{\mathbf{2}} \times \mathbf{1 0 0 \%} \\
& =(0,869)^{2} \times 100 \% \\
& =75,5 \%
\end{aligned}
$$

Berdasarkan perhitungan tersebut diketahui nilai koefisien determinasi sebesar 75,5\% yang artinya variabel lingkungan kerja memberikan kontribusi terhadap variabel kinerja karyawan sebesar 75,5\%. Sedangkan sisanya sebesar 22,5\% disebabkan oleh faktor lain yang tidak diteliti oleh penulis seperti : disiplin kerja, motivasi, gaya kepemimpinan, kompensasi dan variabel lainnya.

\section{Uji Hipotesis}

Uji hipotesis dilakukan untuk mengetahui besarnya pengaruh masing-masing variabel independen terhadap variabel dependen. Sebagai pembanding untuk melihat pengaruh signifikan, maka digunakan kriteria taraf signifikan sebesar 5\% (0.05) dan membandingkan $t_{\text {hitung }}$ dengan $t_{\text {tabel. }}$. Adapun ketentuan mencari nilai $t_{\text {tabel }}$ diperoleh dengan cara jumlah responden $n=40-2=38$ dilihat dari distribusi nilai $t_{\text {tabel }}$ maka nilai $t_{\text {tabel }} 2,024$. Hasil pengujian hipotesis dengan rumus sebagai berikut :

$$
\begin{aligned}
& \mathrm{t} \text {-hitung }=\frac{\mathrm{r} \sqrt{\mathrm{n}-2}}{\sqrt{1-\mathrm{r}^{2}}} \\
& \mathrm{t}=\frac{0,869 \sqrt{40-2}}{\sqrt{1-0,869^{2}}} \\
& \mathrm{t}=\frac{0,869 \sqrt{38}}{\sqrt{1-0,7553}}
\end{aligned}
$$


$\mathrm{t}=\frac{0,869 \times 6,16441}{0,49468}$
$\mathrm{t}=\frac{5,357341}{0,49468}=10,83$

Berdasarkan hasil perhitungan tersebut dapat diketahui bahwa nilai $t_{\text {hitung }} 10,83>t_{\text {tabel }}$ 2,024. Sesuai dengan kriteria Jika thitung $>t_{\text {tabel, }}$ maka $H_{0}$ ditolak dan $H_{a}$ diterima, artinya terdapat pengaruh positif dan signifikan lingkungan kerja terhadap kinerja karyawan Pada PT National Finance.

\section{Pembahasan}

Berdasarkan hasil pengujian statistik dapat diketahui bahwa lingkungan kerja berpengaruh positif dan signifikan terhadap kinerja karyawan hal tersebut dapat dilihat dari persamaan regresi linier sederhana $Y=2,684+1,157 X$ artinya nilai (a) atau konstanta sebesar 2,684 nilai ini menunjukan bahwa pada saat lingkungan kerja (X) bernilai nol atau tidak meningkat, maka kinerja karyawan (Y) akan tetap bernilai 2,684 koefisien regresi nilai (b) sebesar 1,157 (positif) yaitu menunjukkan pengaruh yang searah yang artinya jika lingkungan kerja ditingkatkan sebesar satu satuan maka akan meningkatkan kinerja karyawan sebesar 1,157 satuan. Nilai korelasi sebesar 0,869 yang artinya tingkat kekuatan hubungan lingkungan kerja terhadap kinerja karyawan memiliki tingkat hubungan yang sangat kuat. Nilai R Square sebesar 0,755, yang artinya bahwa lingkungan kerja memberikan kontribusi sebesar 77,5\% terhadap kinerja karyawan. Sedangkan sisanya sebesar 22,5\% disebabkan oleh faktor lain yang tidak diteliti oleh penulis. Dan $t_{\text {hitung }} 10,83>t_{\text {tabel }} 2,024$. Sesuai dengan kriteria Jika $t_{\text {hitung }}>$ tabel, maka H0 ditolak dan Ha diterima, artinya terdapat pengaruh positif dan signifikan lingkungan kerja terhadap kinerja karyawan Pada PT National Finance.

Hasil penelitian ini sejalan dengan penelitian Yuliana dkk (2017), yang berjudul "Pengaruh Lingkungan Kerja, Disiplin Kerja, Dan Kepuasan Kerja Terhadap Kinerja Karyawan BMT Taruna Sejahtera Ungaran". Dimana hasil penelitian menunjukan bahwa Lingkungan kerja berpengaruh positif signifikan terhadap kinerja. Juga didukung oleh Penelitian Sari dan Sofyan (2018) yang berjudul "Pengaruh Lingkungan Kerja, Disiplin Kerja Dan Kepuasan Kerja Terhadap Kinerja Pegawai PT. Fumindo Abdi Lestari Medan”. Memberikan hasil bahwa Lingkungan kerja berpengaruh positif signifikan terhadap kinerja pegawai.

\section{Keterbatasan dan Agenda Penelitian Mendatang}

Penelitian ini hanya mengambil sampel dari Karyawan bagian back office PT National Finance. Penelitian tidak mengambil obyek yang lebih luas, sehingga generalisasi hasil hanya dikhususkan pada Karyawan back office PT National Finance. Masih tingginya keengganan karyawan dalam menjawab pertanyaan-pertanyaan penelitian sesuai dengan keadaan sebenarnya. Untuk penelitian selanjutnya, kerangka penelitian diperluas, untuk melihat apakah ada hubungan dua arah antara satu variabel dengan variabel lainnya.

\section{Kesimpulan}

Berdasarkan hasil penelitian pada PT National Finance, maka dapat diambil kesimpulan sebagai berikut: Lingkungan kerja berpengaruh positif dan signifikan terhadap kinerja karyawan Pada PT National Finance, hal tersebut dapat dibuktikan dari nilai thitung 10,830> $t_{\text {tabel }}$ 2,024. Hal tersebut menandakan bahwa semakin baik kondisi lingkungan kerja sekitar maka akan semakin meningkatkan kinerja karyawan Pada PT National Finance. Besarnya pengaruh lingkungan kerja terhadap kinerja karyawan Pada PT National Finance sebesar 77,5\%. Tingkat kekuatan hubungan lingkungan kerja terhadap kinerja karyawan Pada PT National Finance sebesar 0,869, yang artinya memiliki tingkat hubungan yang sangat kuat. 


\section{Daftar Pustaka}

Abdul H., \& Zulkifli (2018). Pengaruh Lingkungan Kerja Dan Disiplin Kerja Serta Motivasi Kerja Terhadap Kinerja Karyawan. Jurnal Dimensi. DOI: https://doi.org/10.33373/dms.v7i2.1702

Adi, A.S.C., \& Soehari, T.D. (2016). Pengaruh Kepemimpinan, Lingkungan Kerja Dan Kepuasan Kerja Terhadap Kinerja Karyawan PT. SIG. Manajerial. 9(2). DOI: http://dx.doi.org/10.31479/m.v9i2.22

Afandi, P. (2018). Manajemen Sumber Daya Manusia (Teori, Konsep dan. Indikator). Riau: Zanafa Publishing.

Arikunto, S. (2016). Prosedur Penelitian Suatu Pendekatan Praktik, Jakarta: Rineka. Cipta.

Bintoro dan Daryanto. (2017). Manajemen Penilaian Kinerja Karyawan. Yogyakarta: Gava. Media.

Ghozali, I. (2016). Aplikasi Analisis Multivariete Dengan Program. IBM SPSS 23 (Edisi 8). Cetakan ke VIII. Semarang: Universitas Diponegoro.

Handoko, T.H. (2015). Manajemen. Edisi 2. Yogyakarta: BPFE.

Hasibuan, M. S. P. (2016). Manajemen Sumber Daya Manusia. Jakarta: PT Bumi Aksara.

Husein, U. (2014). Metode Penelitian untuk Skripsi dan Tesis Bisnis. Jakarta : PT.Raja Grafindo Persada.

Johan, S. (2017). Analisis Struktur Industri Pembiayaan Indonesia. Jurnal Muara Ilmu Ekonomi dan Bisnis. 1(1) hlm 18-25.

Kasmir. (2016). Manajemen Sumber Daya Manusia (Teori dan Praktik). Depok: PT. Rajagrafindo Persada.

Kembau, R.P.H. (2014). Pengaruh Rasio Hutang dan Rasio Kredit Terhadap Profitabilitas dan Dampaknya Terhaap Rasio Lancar Pada Perusahaan Leasing Yang Terdaftar di IDX. Jurnal EMBA. 2(1). DOI: https://doi.org/10.35794/emba.v2i4.6339

Kusniawati, A., Nurhayati., \& Herlina, R. (2014). Pengaruh Lingkungan Kerja Dan Disiplin Kerja Terhadap Kinerja Karyawan Pada PT Gapuraning Rahayu Ciamis. Jurnal ilmu manajemen. 1(1). DOI: http://dx.doi.org/10.2827/jeim.v1i1.14

Mangkunegara, A.P. (2016). Manajemen Sumber Daya Manusia Perusahaan. Bandung: PT. Remaja Rosdakarya.

Minggu M.M., Lengkong, V.P.K., \& Rumokoy, F.S. (2019). Pengaruh Lingkungan Kerja, Disiplin Kerja Dan Komitmen Organisasi Terhadap Kinerja Karyawan Di PT. Air Manado. Jurnal EMBA. 7(1). DOI: https://doi.org/10.35794/emba.v7i2.23229

Nugrahaningsih, H., \& Julaela (2017). Pengaruh Disiplin Kerja Dan Lingkungan Kerja Terhadap Kinerja Karyawan Dengan Kepuasan Kerja Sebagai Variabel Intervening Pada PT. Tempuran Mas. Jurnal Online Internasional \& Nasional. 4(1). DOI: https://doi.org/10.52447/mmj.v4i1.712

Palampanga, Z. (2017). Pengaruh Kepemimpinan, Lingkungan Kerja Dan Disiplin Kerja Terhadap Kinerja Pegawai Kelurahan Di Wilayah Kecamatan Ampana Kota Kabupaten Tojo Una-Una. Katalogis. 5(10).

Pramadita, A.A.G.O., \& Surya, I.B.K. (2015). Pengaruh Motivasi, Disiplin Kerja Dan Lingkungan Kerja Terhadap Kinerja Karyawan Pada PT PLN (PERSERO) Distribusi Di Denpasar Bali. E-Jurnal Manajemen Unud, : https://doi.org/4.24843/EJMUNUD.2015.v04.i08.p01 
Sari, I.K., \& Sofyan (2018). Pengaruh Lingkungan Kerja, Disiplin Kerja Dan Kepuasan Kerja Terhadap Kinerja Pegawai PT. Fumindo Abdi Lestari Medan. Jurnal Riset Manajemen \& Bisnis (JRMB).3(1). DOI: https://doi.org/10.30743/jrmb.v3i1.508

Sedarmayanti. (2017). Manajemen Sumber Daya Manusia. Bandung: Refika. Aditama.

Siagian, S. P. (2015). Manajemen Sumber Daya Manusia. Jakarta: Bumi Aksara.

Sugiyono. (2017). Metode Penelitian Kuantitatif, Kualitatif, dan R\&D. Bandung: Alfabeta.

Supardi. (2013) Aplikasi Statistika dalam Penelitian Konsep Statistika yang Lebih. Komprehensif. Jakarta: Change Publication.

Rivai, Z. V. (2016). Kepemimpinan dan Perilaku Organisasi. Jakarta: Raja Grafindo Persada.

Sutrisno, E. (2017). Manajemen Sumber Daya Manusia. Jakarta: Kencana Prenada Media Group.

Wibowo. (2015). Perilaku Dalam Organisasi. Edisi Kedua. Jakarta: PT Raja Grafindo Persada.

Widodo, S.E. (2015). Manajemen Pengembangan Sumber Daya Manusia. Yogyakarta: Pusaka Pelajar.

Wirawan. (2015). Evaluasi Kinerja Sumber Daya Manusia (Teori, Aplikasi, dan. Penelitian). Jakarta: Salemba Empat.

Yuliana, M., Budi, L., \& Gagah, E. (2017). Pengaruh Lingkungan Kerja, Disiplin Kerja, Dan Kepuasan Kerja Terhadap Kinerja Karyawan BMT Taruna Sejahtera Ungaran. Journal of Management. 3(3).

Yusuf, B. (2015). Manajemen Sumber Daya Manusia Di Lembaga Keuangan Syariah. Jakarta : PT Raja Grafindo Persada. 